\title{
MENINGKATKAN HASIL BELAJAR SISWA KELAS X IPA PADA MATERI BENTUK MOLEKUL MELALUI MODEL PEMBELAJARAN DISCOVERY LEARNING BERBANTUAN PhET SIMULATIONS
}

\author{
MOSES RIKU \\ SMA Negeri 1 Wolowae Nusa Tenggara Timur \\ e-mail: rikumoses@gmail.com
}

\begin{abstract}
ABSTRAK
Untuk meningkatkan hasil belajar siswa pada mata pelajaran kimia pada materi Bentuk Molekul maka dilakukan penelitian tindakan kelas dengan menerapkan model pembelajaran Discovery Learning berbantuan PhET (Physics Education and Technology) Simulations. Penelitian yang dilakukan terhadap 21 peserta didik (9 laki-laki dan 12 perempuan) kelas X IPA SMAN 1 Wolowae Propinsi Nusa Tenggara Timur tahun pelajaran 2019/2020 terjadi dalam dua siklus. Adapun teknik pengumpulan data yang dilakukan dalam penelitian ini adalah dengan metode test. Data hasil penelitian yang diperoleh dianalisis menggunakan metode deskriptif. Hasil penelitian menunjukan bahwa terjadi peningkatan hasil belajar siswa dari rata-rata nilai 71,43 pada siklus I menjadi 82,86 pada siklus II. Hasil penelitian menunjukkan bahwa terjadi peningkatan hasil belajar siswa pada materi Bentuk Molekul sebesar 11,43\%. Berdasarkan hasil penelitian dapat disimpulkan bahwa pembelajaran Discovery Learning berbantuan PhET (Physics Education And Technology) simulations dapat meningkatkan hasil belajar siswa pada materi Bentuk Molekul. Oleh karena itu model pembelajaran Discovery Learning berbantuan PhET (Physics Education And Technology) simulations sangat efektif dipakai dalam pembelajaran pada materi yang abstrak seperti Bentuk Molekul dan materi sejenis lainnya.
\end{abstract}

Kata Kunci: Discovery Learning, PhET simulations, Hasil Belajar.

\section{PENDAHULUAN}

Memasuki abad 21 ini, perkembangan ilmu dan teknologi menjadi dasar yang sangat kuat dan penting bagi perkembangan dan kemajuan suatu bangsa. Pembelajaran di sekolah menuntut agar peserta didik dilatih untuk mampu dan siap menjalani kehidupan di masa sekarang dan masa yang akan datang. Pesatnya kemajuan di bidang ilmu dan teknologi berdampak pula pada dunia pendidikan. Hadirnya jaringan internet di sekolah mengharuskan siswa dan guru serta tenaga kependidikan terus belajar dan bekerja dengan menggunakan sarana/fasiltas yang ada. Juliana, et.al., (2017) dalam Widia (2020) berpendapat kegiatan belajar yang optimal merupakan salah satu indikator untuk mewujudkan hasil belajar peserta didik yang optimal pula. Hasil belajar yang optimal juga merupakan salah satu cerminan hasil pendidikan yang berkualitas. Pendidikan yang berkualitas memerlukan sumber daya guru yang mampu dan siap berperan secara profesional dalam lingkungan sekolah dan masyarakat. Permatasari et al. (2016) dalam Fadloli, dkk. (2014) berpendapat bahwa pembelajaran di beberapa sekolah selama ini terlihat kurang menarik disebabkan guru sering menerapkan metode ceramah dalam pembelajaran sehingga mengakibatkan siswa merasa jenuh dan kurang berminat, suasana kelas cendrung pasif. Oleh karena itu sangat diperlukan suatu media pembelajaran yang mampu memberikan motivasi kepada siswa dalam pembelajaran. Demikian halnya Widana, et.al. (2019) dalam dalam Widia (2020) mengatakan bahwa dalam era perkembangan iptek yang begitu pesat dewasa ini profesionalisme guru tidak cukup hanya dengan kemampuan membelajarkan siswa tetapi juga harus mampu mengelola informasi dan lingkungan untuk memfasilitasi kegiatan belajar siswa. Pembelajaran yang berkualitas harus didukung dengan media pembelajaran untuk memudahkan guru dan siswa dalam mempelajari materi pembelajaran yang bersifat abstrak. Nurseto dalam Fadloli, dkk.(2019) berpendapat bahwa media pembelajaran memiliki beberapa manfaat yaitu menyamakan persepsi siswa, mengkonkritkan konsep-konsep yang abstrak, menampilkan objek yang terlalu besar atau kecil, 
dan memperlihatkan gerakan yang terlalu cepat atau lambat. Media pembelajaran dapat menarik minat siswa untuk lebih fokus pada materi yang sedang dipelajari. Ketika fokus dan perhatian siswa tertuju pada materi yang sedang dipelajari maka sangat mungkin tujuan pembelajaran akan tercapai.

Pengalaman peneliti dalam pembelajaran kimia tahun-tahun sebelumnya ada kesulitan menjelaskan materi Bentuk Molekul kepada siswa. Metode yang diterapkan dalam pembelajaran hanya terbatas pada metode ceramah dan atau tanya jawab. Sarana/media pendukung pembelajaran Bentuk Molekul yang digunakan hanya mollymood sederhana yang terbuat dari bola plastik (rexona) bekas. Keaktifan siswa dalam pembelajaran Bentuk Molekul sedikit berkurang disebabkan siswa hanya mendengarkan ceramah dari guru. Hal ini sangat berpengaruh pada hasil belajar siswa. Rata-rata hasil penilaian harian materi Bentuk Molekul berada di bawah standar Kriteria Ketuntasan Minimal (KKM). Ketika lembaran hasil penilaian harian dibagikan sebagian siswa bersikap acuh tak acuh, hal ini disebabkan karena siswa sudah menduga bahwa hasil penilaian hariannya tidak mencapai standar KKM (Nilai KKM sekolah=75). Sebagai imbas dari hasil belajar yang tidak mencapai nilai KKM maka siswa cendrung apatis dalam kegiatan pembelajaran selanjutnya.

Hasil belajar adalah perubahan tingkah laku siswa secara nyata setelah dilakukan proses belajar mengajar sesuai dengan tujuan pembelajaran (Jihad, dkk. 2008). Sedangkan Sujana (2004) berpendapat bahwa hasil belajar adalah kemampuan-kemampuan yang dimiliki siswa setelah ia menerima belajarnya. Guru harus benar-benar menekankan pada aktivitas dan kreativitas individu peserta didik agar terlibat aktif dan kreatif di dalam merespons materi pelajaran yang disampaikan dalam kelas (Mulyasa, 2006). Penelitian Tindakan Kelas dalam pembelajaran Bentuk Molekul kali ini adalah model pembelajaran yang dilakukan dengan menerapkan pembelajaran Discovery Learning berbantuan PhET (Physics Education and Technology) Simulations. Proses pembelajaran dilakukan dengan menggunakan media software yang dikenal sebagai PhET (Physics Education and Technology) Simulations.

Menurut Nurseto (2011), media pembelajaran adalah wahana penyalur pesan dan informasi belajar, penggunaan media pembelajaran dapat memperlancar proses pembelajaran dan mengoptimalkan hasil belajar. Budiningsih (2005) dalam Widia (2020) berpendapat bahwa Discovery Learning adalah memahami konsep, arti, dan hubungan, melalui proses intuitif untuk akhirnya sampai kepada suatu kesimpulan. Sedangkan Widana, et.al (2019) dalam Widia (2020); model pembelajaran Discovery Learning dapat mengembangkan cara belajar siswa aktif dengan menemukan sendiri, menyelidiki sendiri, maka hasil yang diperoleh akan tahan lama dalam ingatan, tidak akan mudah dilupakan siswa. PhET (Physics Education and Technology) simulation merupakan sebuah software pembelajaran yang berasal dari Universitas Colorado. PhET ( Physics Education and Technology) simulation digunakan untuk mensimulasi interaktif fenomena-fenomena fisis berbasis riset yang diberikan secara gratis untuk ilmu fisika, ilmu kimia, ilmu biologi, ilmu kebumian dan matematika.

Zahara, dkk (2015) dalam Widia (2020) berpendapat bahwa; terdapat perbedaan peningkatan hasil belajar dan keterampilan berpikir kritis siswa pada kelas kontrol dan kelas eksperimen. Kelas eksperimen yang menggunakan simulasi PhET mengalami peningkatan hasil belajar dan keterampilan berpikir kritis yang lebih tinggi daripada kelas kontrol yang menggunakan pembelajaran konvensional dalam sebuah penelitian: "Penggunaan Media Komputer Berbasis Simulasi Physics Education Technology (PhET) terhadap Hasil Belajar dan Keterampilan Berpikir Kritis Siswa pada Materi Fluida Statis". Media PhET simulation dapat digunakan untuk melakukan simulasi perubahan dan pengolahan data yang bervariasi, simulasinya dapat mengajak siswa untuk belajar dengan cara mengeksplorasi secara langsung, membuat animasi yang abstrak seperti: atom, elektron dan molekul. Pembelajaran materi Bentuk Molekul akan mudah dipahami oleh siswa jika dibantu dengan media pendukung yakni PhET (Physics Education and Technology) simulation. Trianto (2007) berpendapat bahwa dalam mengajarkan sesuatu pokok bahasan (materi) tertentu harus dipilih model pembelajaran yang paling sesuai dengan tujuan yang akan dicapai. 


\section{METODE PENELITIAN}

Penelitian ini dilakukan di SMAN 1 Wolowae Kabupaten Nagekeo Propinsi Nusa Tenggara Timur yang beralamat di Jalan Jurusan Pantura Mbay-Maumere. Populasi penelitian adalah siswa kelas X sedangkan sampel yang diteliti adalah siswa kelas X IPA berjumlah 21 orang ( 9 laki-laki dan 12 perempuan). Penelitian dilakukan pada semester 1 tahun pelajaran 2019/2020. Penelitian dilakukan guna mengetahui hasil belajar siswa dengan menerapkan model pembelajaran Discovery Learning berbantuan PhET (Physics Education Technology ) simulations. Penelitian dilakukan dalam 2 siklus dengan tahapan yang sama di kedua siklus yakni; merencanakan tindakan, melakukan tindakan, mengamati/mengumulkan data dan melakukan refleksi. Langkah-langkah penelitian dapat dilihat pada bagan dalam gambar 1.

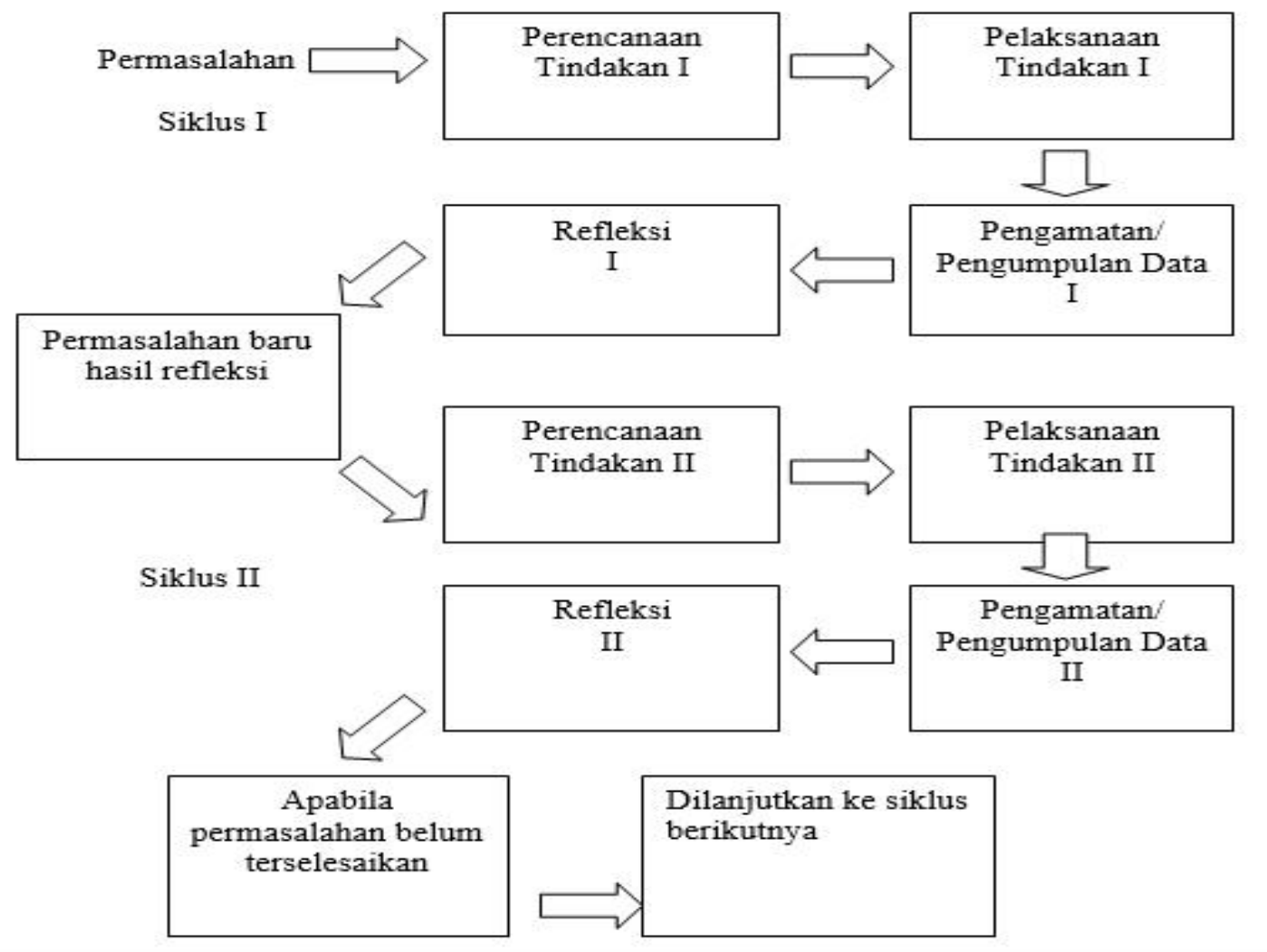

Gambar 1: Langkah-langkah penelitian

Berdasarkan bagan dalam gambar di atas maka langkah-langkah penelitian diuraikan sebagai berikut: 1) tahap merencanakan meliputi kegiatan menyususn Rencana Pelaksanaan Pembelajaran, merumuskan masalah, melakukan studi pendahuluan, merumuskan masalah, memilih stategi/pendekatan, menentukan variabel, menentukan sumber data, meyiapkan alat dan bahan, menyusun instrumen penilaian dan membuat lembaran observasi; 2) tahap melakukan tindakan berupa pelaksanaan kegiatan pembelajaran dengan penekanan pada penerapan model Discovery Learning berbantuan PhET (Physics Education Technology ) simulation serta melakukan uji terhadap materi pembelajaran; 3) pengamatan meliputi kegiatan mengamati aktivitas siswa dalam pembelajaran model Discovery Learning berbantuan PhET (Physics Education Technology ) simulation; 4) tahap melakukan refleksi terhadap pembelajaran yang telah dilakukan dengan model Discovery Learning berbantuan PhET (Physics Education Technology ) simulation. Secara umum tahapan-tahapan yang telah dilakukan merupakan keseluruhan tahapan yang dilakukan pada siklus pertama (siklus I). Jika pada tahapan-tahapan ini terdapat kekurangan yang menyebabkan hasil belajar siswa masih belum mengalami peningkatan yang signifikan maka perlu direkam/dicatat karena hasil refleksi 
pada siklus ini akan digunakan sebagai acuan untuk perbaikan tindakan pada siklus kedua (siklus II).

Untuk mengukur hasil belajar siswa selama proses pembelajaran maka metode tes merupakan salah satu teknik pengumpulan data yang digunakan dalam penelitian ini. Selain mengukur hasil belajar siswa, kegiatan pengamatan/observasi pun dilakukan untuk merekam/mencatat segala peristiwa yang terjadi selama tindakan perbaikan pembelajaran dengan model Discovery Learning berbantuan PhET (Physics Education Technology ) simulation. Data hasil penelitian dianalisis dengan teknik deskritif kuantitatif, yakni memaparkan secara sederhana angka-angka (nilai) yang diperoleh siswa dalam pembelajaran dengan model Discovery Learning berbantuan PhET (Physics Education Technology ) simulation. Hasilnya berupa pencapaian nilai rata-rata, daya serap serta ketuntasan pembelajaran secara klasikal. Indikator keberhasilan pembelajaran dengan model Discovery Learning berbantuan PhET (Physics Education Technology ) simulation adalah nilai rata-rata siswa mencapai KKM $\geq 75$ dan secara klasikal mencapai KKM $\geq 85 \%$.

\section{HASIL DAN PEMBAHASAN}

\section{Hasil Penelitian Pra-Siklus}

Hasil penelitian yang diperoleh pada tahap ini adalah berupa hasil riil yang didapat dari hasil penilaian harian sebelum dilakukan pembelajaran dengan model Discovery Learning berbantuan PhET (Physics Education Technology ) simulation. Hasil belajar siswa pra-siklus dapat dilihat pada Tabel 1 .

Tabel 1. Hasil Belajar Siswa Pra-Siklus.

\begin{tabular}{clcc}
\hline No. & Uraian & Nilai & \% Siswa \\
\hline 1. & Nilai Terendah & 20 & 14,29 \\
2. & Nilai Tertinggi & 90 & 4,76 \\
3. & Nilai Rata-Rata & 43,81 & 80,95
\end{tabular}

Data hasil penelitian pembelajaran yang diperoleh selanjutnya diolah secara deskriptif. Berdasarkan data di atas, hasil belajar siswa pada pembelajaran Bentuk Molekul masih sangat rendah. Prosentase ketuntasan belajar dan ketercapaian KKM pada tahap ini secara klaiskal belum tercapai. Faktor utama penyebab rendahnya hasil belajar siswa adalah kurangnya pemahaman konsep siswa pada materi Bentuk Molekul. Materi ini jika dibandingkan dengan materi kimia lainnya dalam tingkatan yang sama sedikit lebih sulit karena bersifat abstrak. Selain itu proses pembelajaran yang dilakukan masih bersifat konvensional berupa ceramah serta tidak didukung dengan sarana/media bantu pembelajaran untuk mempermudah pemahaman siswa.

\section{Hasil penelitian siklus I}

Salah satu model pembelajaran yang dapat meningkatkan hasil belajar siswa pada materi Bentuk Molekul adalah pembelajaran model Discovery Learning berbantuan PhET (Physics Education Technology ) simulations.

Langkah-langkah penelitian pada siklus I meliputi: 1) tahap merencanakan penyusunan Rencana Pelaksanaan Pembelajaran, merumuskan masalah, melakukan studi pendahuluan, merumuskan masalah, memilih stategi/pendekatan, menentukan variabel, menentukan sumber data, meyiapkan alat dan bahan, menyusun instrumen penilaian dan membuat lembaran 
observasi; 2) tahap melakukan tindakan berupa pelaksanaan kegiatan pembelajaran dengan penekanan pada penerapan model Discovery Learning berbantuan PhET (Physics Education Technology ) simulation serta melakukan uji terhadap materi pembelajaran; 3) pengamatan meliputi kegiatan mengamati aktivitas siswa dalam pembelajaran model Discovery Learning berbantuan PhET (Physics Education Technology ) simulation; 4) tahap melakukan refleksi terhadap pembelajaran yang telah dilakukan dengan model Discovery Learning berbantuan PhET (Physics Education Technology ) simulation. Hasil belajar siswa siklus I dapat dilihat pada Tabel 2.

\begin{tabular}{|c|c|c|c|}
\hline No. & Uraian & Nilai & $\%$ Siswa \\
\hline 1. & Nilai Terendah & 40 & 9,52 \\
\hline 2. & Nilai Tertinggi & 100 & 4,76 \\
\hline 3. & Nilai Rata-Rata & 71,43 & 85,71 \\
\hline
\end{tabular}

Berdasarkan data di atas, terlihat ada peningkatan hasil belajar siswa di siklus I jika dibandingkan dengan pra-siklus meskipun belum semua siswa menunjukkan hasil mencapai standar KKM. Hasil pengamatan pembelajaran dengan model Discovery Learning berbantuan PhET (Physics Education Technology ) simulations, banyak anak laki-laki sudah mulai aktif dalam kegiatan simulasi sedangkan anak perempuan kelihatan masih ragu-ragu, takut dan sedikit malu. Hasil refleksi peneliti terhadap hasil belajar siswa pada siklus I sejauh ini masih berada pada taraf wajar, hal ini disebabkan karena pembelajaran menggunakan model Discovery Learning berbantuan PhET (Physics Education Technology ) simulations baru pertama kali dilakukan. Penerapan model pembelajaran yang baru seperti ini cukup berpengaruh pada persiapan dan kesiapan guru maupun siswa. Pada pengelolaan kelas di siklus I terjadi perubahan dari biasanya terutama waktu pembelajaran menjadi molor tidak sesuai lagi dengan alokasi waktu yang disiapkan. Penilaian akhir pembelajaran dilakukan dengan tergesagesa karena sebagian besar waktu pembelajaran dipakai untuk simulasi. Faktor penyebab lain adalah persiapan dan kesiapan guru dalam menerapkan model pembelajaran baru masih kurang, demikian juga siswa masih belum terbiasa dengan model pembelajaran yang baru.

Pada pembelajaran siklus I, pengelolan kelas yang dilakukan belum optimal; masih terdapat siswa yang kurang serius mengikuti pembelajaran, siswa tertentu saja yang mendominasi pembelajaran dengan PhET (Physics Education Technology) simulations. Ada juga siswa/kelompok siswa yang menggunakan media PhET (Physics Education Technology) simulations hanya sekedar menunjukan kepada siswa/kelompok siswa lainnya bahwa mereka bisa mengoperasikannya. Kesan siswa menunjukan bahwa guru tidak melakukan pengajaran sebagaimana biasa. Guru hanya mengontrol aktivitas siswa dan memberikan penjelasan seperlunya kepada siswa/kelompok siswa yang membutuhkan. Penerapan pembelajaran dengan model Discovery Learning berbantuan PhET (Physics Education Technology ) simulations, sesungguhnya guru telah melaksanakan perannya yaitu sebagai fasilitator, siswa sendiri yang mengonstruksikan pembelajaran. Hal seperti ini perlu ditekankan kepada siswa dalam pembelajaran selanjutnya.

Hal positif yang diperoleh dalam pembelajaran model Discovery Learning berbantuan PhET (Physics Education Technology ) simulations pada siklus I adalah bahwa keaktifan siswa sudah mulai meningkat dibandingkan pembelajaran sebelumnya dengan metode ceramah. Siswa yang sebelumnya lebih banyak diam menjadi aktif dan sudah mulai berkomunikasi walau percakapan baru terjadi di dalam kelompok. Pembelajaran Bentuk Molekul yang dirasa abstrak 
dan sulit menjadi lebih mudah dipahami siswa. Sebagian siswa di dalam kelompok ada yang secara spontan mengatakan kalau seperti ini berarti mempelajari Bentuk Molekul sebenarnya tidak sulit. Sikap rasa percaya diri, kerjasama, rasa ingin tahu serta saling menghargai di antara siswa di dalam kelompok sudah mulai terlihat.

Hasil penelitian yang diperoleh pada siklus I menunjukkan bahwa ketercapain hasil belajar siswa secara klasikal belum mencapai $85 \%$. Hal ini berarti masih harus dilakukan penelitian ke siklus berikutnya yaitu siklus II. Tindakan yang dilakukan pada siklus II sedikit berbeda dengan siklus pertama dimana kekurangan/kelemahan yang terjadi di siklus pertama harus diperbaiki pada siklus II. Pengelolaan pembelajaran pada siklus II dilakukan secara lebih baik dengan memanfaatkan media pembelajaran model Discovery Learning berbantuan PhET (Physics Education Technology ) simulations secara optimal.

\section{Hasil penelitian siklus II}

Pada siklus II ini guru telah melakukan perbaikan terhadap kelemahan/kekurangan yang dilakukan di siklus sebelumnya (siklus I). Pengelolaan kelas dilakukan secara lebih baik dengan mengoptimalkan pembelajaran model Discovery Learning berbantuan PhET (Physics Education Technology ) simulations. Waktu belajar yang sebelumnya di siklus I molor sehingga penilaian akhir menjadi tergesa-gesa, kali ini dilakukan secara optimal. Sebagian besar siswa sudah lebih aktif dalam belajar dibandingkan pada siklus I. Hasil belajar siswa siklus 2 dapat dilihat pada Tabel 3.

Tabel 3. Hasil Belajar Siswa Siklus II.

\begin{tabular}{clcc}
\hline No. & Uraian & Nilai & \% Siswa \\
\hline 1. & Nilai Terendah & 60 & 9,52 \\
2. & Nilai Tertinggi & 100 & 14,29 \\
3. & Nilai Rata-Rata & 82,86 & 76,19
\end{tabular}

Berdasarkan data di atas, hasil belajar siswa pada siklus II menunjukan bahwa telah terjadi ketuntasan belajar secara klasikal (85.71\%). Suatu penelitian dinyatakan selesai jika telah memenuhi syarat ketuntasan yaitu nilai rata-rata siswa mencapai KKM $\geq 75$ dan kentuntasan belajar secara klasikal mencapai $\mathrm{KKM} \geq 85 \%$. Hal yang menyebabkan pembelajaran di siklus II nilai rata-rata mencapai standar KKM adalah pada siklus II guru sudah melakukan perbaikan terhadap kelemahan/kekurangan yang terjadi di siklus pertama pembelajaran Bentuk Molekul dengan menggunakan media PhET (Physics Education Technology ) simulations. Dari sisi siswa, mereka sudah terbiasa dengan model pembelajaran yang dilakukan. Pembelajaran Bentuk Molekul dengan menggunakan media PhET (Physics Education Technology ) simulations dapat membuat siswa lebih aktif dan semangat dalam pembelajaran. Sikap ilmiah seperti berpikir kritis serta memiliki rasa ingin tahu terhadap pembelajaran Bentuk Molekul serta sejumlah keterampilan nampak jelas sebagai akibat dilakukan simulasi pembelajaran model Discovery Learning berbantuan PhET (Physics Education Technology ) simulations.

Zainudin (2017) dalam Widia (2020) dalam penelitiannya berjudul Pengembangan $E$ Learning Fisika Menggunakan PhET (Physics Educational Technology) pada Materi Pokok Dinamika Gerak Lurus berbasis Keterampilan Berpikir Kritis, mengungkapkan bahwa pembelajaran dengan penggunaan media PhET dapat: (1) meningkatkan motivasi dan minat peserta didik pada materi pokok dinamika gerak lurus; (2) respon peserta didik terhadap implementasi pembelajaran menggunakan PhET dalam kategori baik; (3) hasil belajar peserta didik secara klasikal meningkat; (4) keterampilan siswa melakukan percobaan lebih baik dibandingkan dengan sebelum menggunakan PhET karena peserta didik terinspirasi dari simulasi PhET. 
Perbandingan hasil belajar siswa pada pembelajaran Bentuk Molekul pra-siklus dengan setelah dilakukan pembelajaran model Discovery Learning berbantuan PhET (Physics Education Technology ) simulations ditunjukkan pada Tabel 4.

Tabel 4. Perbandingan hasil belajar siswa pada pembelajaran Bentuk Molekul pra-siklus dengan setelah dilakukan pembelajaran model Discovery Learning berbantuan PhET (Physics

Education Technology ) simulations

\begin{tabular}{clccc}
\hline No. & Uraian & Pra Siklus & Siklus 1 & Siklus II \\
\hline 1. & Nilai Terendah & 20 & 40 & 60 \\
2. & Nilai Tertinggi & 90 & 100 & 100 \\
3. & Nilai Rata-Rata & 43,81 & 71,43 & 82,86 \\
4. & Prosentase & $14,29 \%$ & $47,62 \%$ & $85,71 \%$ \\
\hline
\end{tabular}

Berdasarkan hasil analisis data di atas diperoleh bahwa model pembelajaran Discovery Learning berbantuan media PhET (Physics Education Technology) simulations dapat meningkatkan hasil belajar siswa pada pembelajaran Bentuk Molekul. Pada siklus I nilai rata mencapai 71,43 dan siklus 2 mencapai 82,86. Ketuntasan belajar secara klasikal juga mengalami peningkatan dari $47,62 \%$ pada siklus I menjadi $85,71 \%$ pada siklus II. Secara keseluruhan hasil belajar siswa mulai dari pra-siklus, siklus I dan siklus II dapat dilihat pada grafik 1.
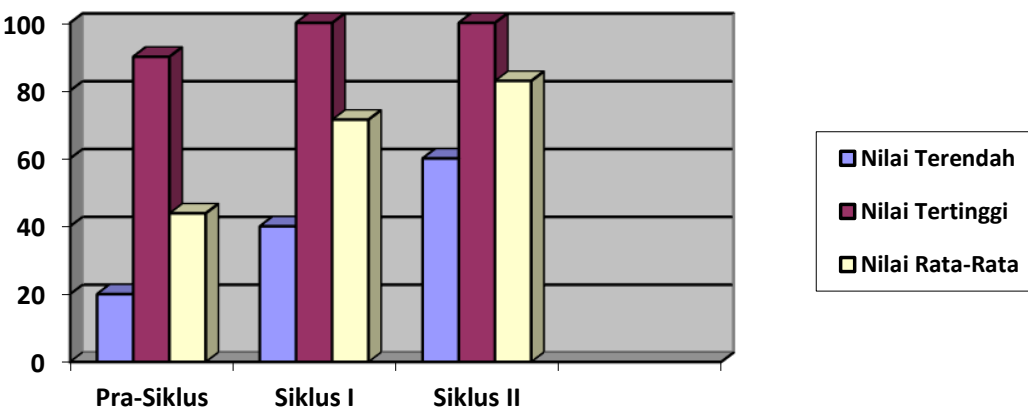

Gambar 2: Grafik Hasil Belajar Siswa Pra-siklus, Siklus I dan Siklus II

Penelitian tindakan kelas yang dilakukan di SMAN 1 Wolowae pada kelas X IPA memiliki dasar permasalahan yakni kemampuan belajar siswa pada materi bentuk molekul sangat rendah. Hal ini disebabkan materi Bentuk Molekul sedikit abstrak dan membutuhkan penalaran. Secara kualitatif, sebagaimana refleksi awal kemampuan dasar siswa SMAN 1 Wolowae dalam mengikuti pembelajaran pada materi bentuk molekul sangat rendah. Kebanyakan dari mereka hanya mengandalkan konsep yang diberikan guru saat pembelajaran di kelas dengan metode ceramah. Jarang siswa menemukan konsep sendiri dari pengetahuan yang mereka dapat dari buku bacaan ataupun sumber lain. Mereka hanya mencatat materi yang dijelaskan guru dan jarang untuk menemukan konsep-konsep baru tentang materi yang dipelajari melalui kegiatan praktek di laboratorium ataupun demonstrasi dalam pembelajaran yang dilakukan di kelas. Hal inilah yang menyebabkan siswa mengalami kesulitan dalam memahami konsep pembelajaran kimia khusunya Bentuk Molekul. Widana (2017) berpendapat bahwa keberhasilan suatu pembelajaran dapat dilihat dari meningkatnya kemampuan belajar siswa secara mandiri sehingga pengetahuan yang dikuasai siswa adalah hasil belajar yang dilakukannya sendiri.

Berdasarkan refleksi awal siklus, maupun pada siklus I dan siklus II, pelaksanaan tindakan pembelajaran Bentuk Molekul dengan model Discovery Learning berbantuan media 
PhET (Physics Education Technology ) simulations dapat merangsang minat dan perhatian siswa karena pembelajarannya mudah, asyik dan menyenangkan serta mudah digunakan baik secara online maupun secara offline di kelas ataupun di rumah. Hasil belajar siswa kelas $\mathrm{X}$ IPA SMAN 1 Wolowae dapat mengalami peningkatan dengan diterapkannya model pembelajaran Discovery Learning berbantuan media PhET (Physics Education Technology) simulations dengan langkah-langkah antara lain; 1) persiapan rencana pelaksanaan pembelajaran (RPP) dengan media PhET (Physics Education Technology ) simulations, 2) pelaksanaan tindakan yang meliputi pemberian rangsangan dengan media PhET, mengidentifikasi masalah, mengumpulkan data, mengolah data dan melakukan verifikasi data hasil penelitian. Bruner dalam Widia (2020) menyatakan bahwa anak harus berperan secara aktif dalam pembelajaran di kelas. Dalam pembelajaran berbasis discovery (penemuan), kegiatan atau pembelajaran dirancang sedemikian rupa sehingga siswa dapat menemukan konsep-konsep dan prinsip-prinsip melalui proses mentalnya sendiri. Dalam menemukan konsep, siswa melakukan pengamatan, menggolongkan, membuat dugaan, menjelaskan, dan menarik kesimpulan untuk menemukan beberapa konsep atau prinsip. Nugrahaeni, A., Redhana, I.W., \& Kartawan, I.M.A. (2017) menunjukan bahwa pembelajaran dengan menggunakan model Discovery Learning terbukti efektif dalam meningkatkan kemampuan berpikir kritis dan hasil belajar kimia.

Dalam pelaksanaan pembelajaran dengan model baru di kelas tentunya mengalami beberapa masalah terutama di awal pelaksanaan. Hal serupa dialami peneliti antara lain; menyusun rencana pelaksaaan pembelajaran (RPP) Bentuk Molekul berbasis Discovery Learning berbantuan media PhET (Physics Education Technology ) simulations, proses mengkondisikan kelas agar semua siswa/kelompok siswa memiliki kesempatan yang sama dalam melakukan PhET (Physics Education Technology ) simulations, membimbing siswa/kelompok siswa dalam kegiatan simulasi ataupun masalah teknis lainnya yang telah dialami selama pembelajaran Bentuk Molekul berlangsung.

Untuk meminimalisir permasalahan yang terjadi selama pembelajaran maka peneliti mengambil langkah di antaranya dengan mempelajari terlebih dahulu skenario dalam RPP Bentuk Molekul dengan model pembelajaran Discovery Learning berbantuan media PhET (Physics Education Technology ) simulations secara matang sebelum diterapkan di kelas dan memberikan bimbingan kepada siswa/kelompok siswa dengan lebih optimal secara bergilir.

\section{KESIMPULAN}

Berdasarkan hasil yang diperoleh dan pembahasan di atas, maka dapat disimpulkan bahwa setelah dilakukan tindakan dengan model pembelajaran Discovery Learning berbantuan media PhET (Physics Education Technology ) simulations pada mata pelajaran kimia dengan materi Bentuk Molekul pada siswa kelas X IPA SMAN 1 Wolowae semester ganjil tahun pelajaran 2019/2020 terjadi peningkatan hasil belajar siswa dari rata-rata nilai 71,43 pada siklus I menjadi 82,86 pada siklus II. Data perkembangan hasil belajar siswa terhadap materi Bentuk Molekul didapatkan dari hasil rata-rata nilai pra-siklus sebesar 43,81, rata-rata nilai siklus I sebesar 71,43 dan rata-rata nilai pada siklus II sebesar 82,86. Peningkatan hasil belajar siswa ini sejalan dengan peningkatan prosentase ketuntutasan belajar, yakni 14,29\% pada prasiklus berubah menjadi $47,62 \%$ pada siklus I. Sedangkan pada siklus II prosentase ketuntutasan belajar meningkat menjadi $85,71 \%$.

Berdasarkan hasil penelitian yang diperoleh diharapkan agar rekan-rekan guru MIPA khususnya guru kimia agar dapat menggunakan model pembelajaran Discovery Learning berbantuan media PhET (Physics Education Technology) simulations dalam pembelajaran kimia khususnya pada materi-materi yang sedikit abstrak.

\section{DAFTAR PUSTAKA}

Asep Jihad, dkk. (2008). Evaluasi Pembelajaran. Yogyakarta: Multi Pressindo.

Fadloli, M., Kusumo, E., \& Kasmui. (2019). Pengembangan Model Pembelajaran Blended Learning Berbasis Edmodo Untuk Pembelajaran Kimia Yang Efektif. Journal of 
Chemistry In Education. CiE ,8 (1), 1-6.

Mulyasa. (2006). Menjadi Guru Profesional (Menciptakan Pembelajaran Kreatif dan Menyenangkan). Bandung; Remaja Rosdakarya.

Nugrahaeni, A., Redhana, I.W., \& Kartawan, I.M.A. (2017). Penerapan Model Pembelajaran Discovery Learning untuk Meningkatkan Kemampuan Berpikir Kritis dan Hasil Belajar Kimia. Jurnal Pendidikan Kimia Indonesia. 1(1), 23-29.

Nurseto, T. (2011). Membuat Media Pembelajaran Yang Menarik. Jurnal Ekonomi dan Pendidikan. 8(1): 19-35.

Permendikbud 2016 No.24, Kompetensi Inti dan Kompetensi Dasar pada Jenjang Pendidikan Dasar dan Menengah.

Sudjana, Nana. (2004). Dasar-Dasar Proses Belajar Mengajar. Bandung: Balai Pustaka.

Trianto. (2007). Model-model Pembelajaran Inovatif. Jakarta: Prestasi Pustaka.

Widana, I.W. (2017). Modul Penyusunan Soal Higher Order Thinking Skill (HOTS). Jakarta: Direktorat Pembinaan SMA Kemdikbud.

Widia, I Wayan. (2020). Penerapan Model Discovery Learning berbantuan Media PhET Untuk Meningkatkan Kompetensi Siswa. Indonesian Journal of Educational Development, 1(2), 262-273, DOI: 10.5281/zenodo.4004185. 